Tropical Journal of Pharmaceutical Research June 2019; 18 (6): 1259-1264

ISSN: $1596-5996$ (print); 1596-9827 (electronic)

(c) Pharmacotherapy Group, Faculty of Pharmacy, University of Benin, Benin City, 300001 Nigeria.

\title{
Celastrus orbiculatus Celastraceae Thunb extracts inhibit proliferation and migration of oral squamous cell carcinoma cells by blocking NF-kB pathway
}

\author{
Deqiang Hou ${ }^{1}$, Ning $\mathrm{Bai}^{2}$, Zicheng Wei ${ }^{1}$, Bang $\mathrm{Li}^{3}$, Genxiong Tang ${ }^{4}$, Yufeng \\ Gao $^{1 *}$ \\ ${ }^{1}$ Department of Stomatology, Affiliated Hospital of Jiangnan University, Wuxi $214000,{ }^{2}$ Department of Endocrinology, Affiliated \\ Hospital of Jiangnan University, Wuxi $214000,{ }^{3}$ Department of Orthodontics of Stomatology, Hefei Stomatological Hospital, \\ Hefei 230000, ${ }^{4}$ Department of Stomatology, Affiliated Children's Hospital of Nanjing Medical University, Nanjing 210008, China
}

*For correspondence: Email: jianghongbingkjh@163.com; Tel: 0086+051088683233

Sent for review: 27 February 2019

Revised accepted: 30 May 2019

\begin{abstract}
Purpose: To investigate the mechanism of action of Celastrus orbiculatus extract (COE) on oral squamous carcinoma cells.

Methods: Tca8113 cells were divided into negative control and three COE treatment groups, viz, 20, 40 , and $80 \mu \mathrm{g} / \mathrm{mL}$ of COE. Succinate dehydrogenase activity assay (MTT assay) and flow cytometry were used to assess cell proliferation and apoptosis. Cell migration and invasion were assessed by Transwell chamber and wound healing assays while relative protein expression was determined by Western blot.

Results: As the concentration of COE increased, the number of cells arrested in the G0/G1 phase increased $(p<0.05)$, expressions of cell-cycle-related proteins decreased $(p<0.001)$; the number of apoptotic cells increased $(p<0.001)$, and the rates of cell migration and invasion decreased $(p<0.001)$. Exogenous COE significantly inhibited $p$-IKBa accumulation in the cytoplasm and induced $I k B \alpha$ accumulation. Nuclear $p 65$ recruitment was reduced in cells treated with COE compared to untreated control cells ( $p<0.001)$, suggesting that the classical NF-KB pathway was blocked by COE.

Conclusion: These results demonstrate that $C O E$ inhibits the proliferation and migration of oral squamous cell carcinoma cells while promoting apoptosis by blocking NF-KB pathway. These findings suggest that Celastrus orbiculatus extract possesses a potential therapeutic effect on oral squamous cell carcinoma.
\end{abstract}

Keywords: Celastrus orbiculatus, Renal impairment, Diabetes, Cell migration, NF-KB pathway

\begin{abstract}
This is an Open Access article that uses a fund-ing model which does not charge readers or their institutions for access and distributed under the terms of the Creative Commons Attribution License (http://creativecommons.org/licenses/by/4.0) and the Budapest Open Access Initiative (http://www.budapestopenaccessinitiative.org/read), which permit unrestricted use, distribution, and reproduction in any medium, provided the original work is properly credited.

Tropical Journal of Pharmaceutical Research is indexed by Science Citation Index (SciSearch), Scopus, International Pharmaceutical Abstract, Chemical Abstracts, Embase, Index Copernicus, EBSCO, African Index Medicus, JournalSeek, Journal Citation Reports/Science Edition, Directory of Open Access Journals (DOAJ), African Journal Online, Bioline International, Open-J-Gate and Pharmacy Abstracts
\end{abstract}

\section{INTRODUCTION}

More than $90 \%$ of oral cancers are squamous cell carcinomas (OSCCs), which originate in the oral mucosa [1]. Oral squamous cell carcinomas is a solid malignant tumor with some of the highest morbidity and mortality rates among head and neck malignant tumors [2]. Despite recent advances in diagnostic, surgical, and chemotherapy strategies, the 5-year survival of 
OSCC patients remains low. Traditional Chinese medicine has shown great potential in cancer treatment and is a potential source of therapeutic drugs for OSCC.

Celastrus orbiculatus Thunb. is the source of a traditional medicine for treating pain and for various inflammatory diseases including arthritis. Studies have shown that $C$. orbiculatus extracts (COE) have a variety of biological properties, including anti-tumor, anti-inflammatory, analgesic, antibacterial, and antiviral effects [3]. C. orbiculatus extracts inhibit the growth and metastasis of various kinds of cancer cells including gastric cancer, colon cancer, and liver cancer. In addition, $C$. orbiculatus extracts induce the apoptosis of tumor cells in vitro and in vivo [4-8].

Nuclear factor-KB is one of the main targets of natural cancer treatment compounds [9]. Nuclear factor- $\mathrm{KB}$ pathways control a variety of cellular functions, including proliferation, survival, cell death, invasion, and angiogenesis [3]. The aim of this study was to investigate the effects of COE on the proliferation and migration of cells of the OSCC line Tca8113 cells and the underlying mechanisms.

\section{EXPERIMENTAL}

\section{Materials}

Celastrus orbiculatus was purchased from Guangzhou Zhixin Pharmaceutical Co. Ltd. The plant material was authenticated by Professor Minjian Qin in 2017 at Chinese Medicine Resources Laboratory of China Pharmaceutical University where a voucher specimen (no. 070510) was deposited in its herbarium. The root portion of Celastrus orbiculatus were cut, ground into powder, and extracted three times with $95 \%$ ethanol for $3 \mathrm{~h}$. The ethanol phase was recovered and extracted three times with petroleum ether and acetic acid. The ethyl acetate layer was collected and washed with water. The crude extract was concentrated and lyophilized to obtain the COE.

Annexin V/propidium iodide (PI) apoptosis and BCA protein assay kits were purchased from Sigma-Aldrich Chemical Company (Shanghai, China). Chemical reagents and the cell-cycle protein markers (CDK2, CDK4, Cyclin D1, and Cyclin E1) were obtained from Merck (Shanghai, China). Dulbecco's modified eagle medium (DMEM), dimethyl sulfoxide (DMSO), 3-(4,5dimethyl-2-thiazolyl)-2,5-diphenyl-2-H-tetrazolium bromide (MTT), fetal bovine serum (FBS), and ethylenediaminetetraacetic acid (EDTA) were from Abcam China.

\section{MTT cell proliferation assay}

Tca8113 cells were seeded in 96-well culture plates with $100 \mu \mathrm{L}$ of DMEM containing $10 \%$ FBS and $1 \%$ penicillin-streptomycin at $5 \times 10^{3}$ cells/well and incubated overnight. After the cells were attached, different concentrations of COE were added, and the cells were incubated for another $24 \mathrm{~h}$ at $37^{\circ} \mathrm{C}$ in a $5 \% \mathrm{CO}_{2}$ atmosphere. The cells in wells without COE served as the negative control. Cell cultural supernatant was discarded, $20 \mu \mathrm{L}$ of MTT was added to each well, and the cells were incubated for another $4 \mathrm{~h}$. The supernatant was discarded and $150 \mu \mathrm{L}$ DMSO was added to each well. The plates were shaken for $10 \mathrm{~min}$ on a micro-oscillator shaking to dissolve the formazan crystals and the absorbance was measured in microplate reader at a wavelength of $490 \mathrm{~nm}$.

Tca8113 cells were seeded in a 6 -well plate at 2 $\times 10^{5}$ cells/well and incubated at $37 \stackrel{\circ}{\circ} \mathrm{C}$ in $5 \%$ $\mathrm{CO}_{2}$ overnight. After this incubation, different concentrations of COE were added to the wells, and they were incubated for another $24 \mathrm{~h}$. At the end of the 24-h incubation, cells were collected by trypsinization without EDTA, washed with PBS, and $100 \mu \mathrm{L}$ of $1 \times$ annexin binding buffer was added to each well with gentle mixing. Next, $5 \mu \mathrm{L}$ of FITC-annexin $\mathrm{V}$ and $1 \mu \mathrm{L}$ PI working solution were added and mixed with the cells at 4 ${ }^{\circ} \mathrm{C}$. Apoptosis was detected by a flow cytometer (Accuri C6, BD, USA).

\section{Cell invasion and migration assay}

Tca8113 cells were seeded in 6-well culture plates at $4 \times 10^{5}$ cells/well with various concentrations of COE and incubated overnight under conditions previously described. The Transwell chambers were prepared by hydrating the membrane of the chamber with $25 \mu \mathrm{L}$ of Matrigel gel dilution and adding DMEM containing $20 \%$ FBS to the lower chamber. The cells were harvested, re-suspended in serumfree DMEM medium, and seeded in the upper layer of the Transwell chamber. After $12 \mathrm{~h}$, cells that had not passed through the upper layer of the chamber and Matrigel glue were removed by wiping. These cells were fixed with methanol for $15 \mathrm{~min}$, then with crystal violet for $30 \mathrm{~min}$, and then washed three times with PBS. The cells that had passed through the lower layer of the chamber were observed under a fluorescence microscope (FV 100, Olympus, Japan). Three fields were randomly selected and counted for 
each group. Cell invasion rate was calculated as in Eq 1.

$R=\{1-(N t / N n)\} 100$

where $N t=$ number of transmembrane cells in the experimental group, and $N n=$ number of transmembrane cells in the negative control group.

\section{Western blot}

Tca8113 cells treated with different concentrations of COE for $24 \mathrm{~h}$ as described above were harvested, and $300 \mu \mathrm{L}$ of cell lysis buffer was added to each dish to lyse the cells. Total protein was quantified with the BCA kit, then was boiled in SDS loading buffer for $5 \mathrm{~min}$ and cellular proteins were separated using SDSPAGE $(10 \%)$ and transferred to a nitrocellulose membrane. The membrane was incubated for $1.5 \mathrm{~h}$ at room temperature with blocking buffer (1 $\%$ skimmed milk and $0.1 \%$ BSA in TTBS). The Membranes were incubated overnight in blocking buffer with the appropriate primary antibodies at $4{ }^{\circ} \mathrm{C}$. The membrane was incubated with the appropriate secondary antibody for $1 \mathrm{~h}$. The immunoreactive protein was visualized with enhanced chemiluminescence.

\section{Wound healing assay}

A pen was used to draw a horizontal line on the back of a 6 -well plate. Tca8113 cells $\left(5 \times 10^{5}\right.$ cells/well) treated with different concentrations of COE were added into each well and incubated for $24 \mathrm{~h}$ as previously described. A scratch was made along the horizontal like and the cells were washed three times with PBS to remove detached cells. Then, serum-free DMEM was added and the cells were incubated at $37^{\circ} \mathrm{C}$. Photographs were taken at 0 and $24 \mathrm{~h}$ for comparison.

\section{Statistical analysis}

All the data are expressed as mean \pm SD. Statistical comparison of mean values between groups was performed by analysis of variance (ANOVA), and $p<0.05$ was considered statistically significant.

\section{RESULTS}

\section{COE inhibited Tca8113 cell proliferation}

MTT assay was used to assess the proliferation of Tca8113 cells. The results are shown in Figure $1 \mathrm{~A}$. After $24 \mathrm{~h}$ of treatment with COE, cell proliferation were, $94,74 \%(p<0.05$ vs. control), and $70 \%$ ( $p<0.01$ vs. control) for COE concentrations of 20,40 , and $80 \mu \mathrm{g} / \mathrm{mL}$, respectively. After $72 \mathrm{~h}$ of $\mathrm{COE}$ treatment, cell proliferation in the presence of 20,40 , and 80 $\mu \mathrm{g} / \mathrm{mL}$ were $74 \%(p<0.01), 64 \%(p<0.001)$, and $38 \%(p<0.001)$, respectively. Compared with 24-h COE treatment, 72-h treatment further reduced proliferation, indicating that the effect of COE on the proliferation of Tca8113 cells was time-dependent. When the cells were treated with COE for $24 \mathrm{~h}$, there was an obvious cytotoxic effect. Therefore, $24 \mathrm{~h}$ is the appropriate treatment time for the experiments.

Flow cytometry results showed that the percentage of the cell population at the G0/G1 stage was increased to $72.69,76.71$, and 78.71 $\%(p<0.05)$ at 20,40 , and $80 \mu \mathrm{g} / \mathrm{mL}$ COE, respectively. The percentage of the cell population at $\mathrm{S}$ and $\mathrm{G} 2 / \mathrm{M}$ stages decreased to 20.81 and $6.67 \%, 16.97$ and $7.18 \%$, and 18.33 and $2.67 \%$ at 20,40 , and $80 \mu \mathrm{g} / \mathrm{mL} \mathrm{COE}$, respectively. The relative levels of cell-cycle proteins were measured by western blot (Figure $1 \mathrm{C})$. Expression of all proteins (CDK2, CDK4, cyclin D1 and cyclin E1) decreased with COE in a dose-dependent manner.

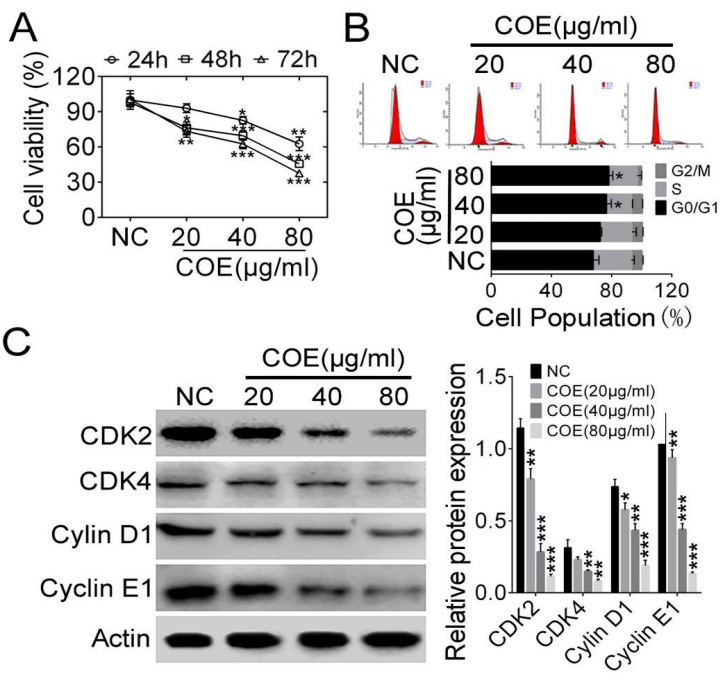

Figure 1: Effect of Celastrus orbiculatus extract (COE) on oral squamous cell carcinoma cell line Tca8113 cell proliferation. A: Cell viability after treatment with various concentration of $\mathrm{COE}$ as measured by flow cytometry. B: Percentage of cells in different cell-cycle phases. C: Relative expression of cell-cycle proteins assessed with western blot; mean \pm SD $(n=5) ;{ }^{*} p<$ $0.05,{ }^{\star \star} p<0.01$, and ${ }^{\star \star \star} p<0.001$, compared to NC group

\section{COE induced Tca8113 cell apoptosis}

Apoptosis of the cells was further analyzed using flow cytometry (Figure $2 \mathrm{~A}$ ). The results showed that COE induced the apoptosis of Tca8113 cells 
in a dose-dependent manner. The proportion of cell necrosis at the highest COE dose was more apparent than in the other groups. The relative levels of apoptosis proteins were measured by western blot (Figure $2 \mathrm{~B}$ ). Expressions of caspase 3, caspase 9, and Bax were increased dose-dependently by COE, whereas $\mathrm{Bcl}-2$ expression decreased. The highest dose of COE treatment showed a more obvious effect on Tca8113 apoptosis.

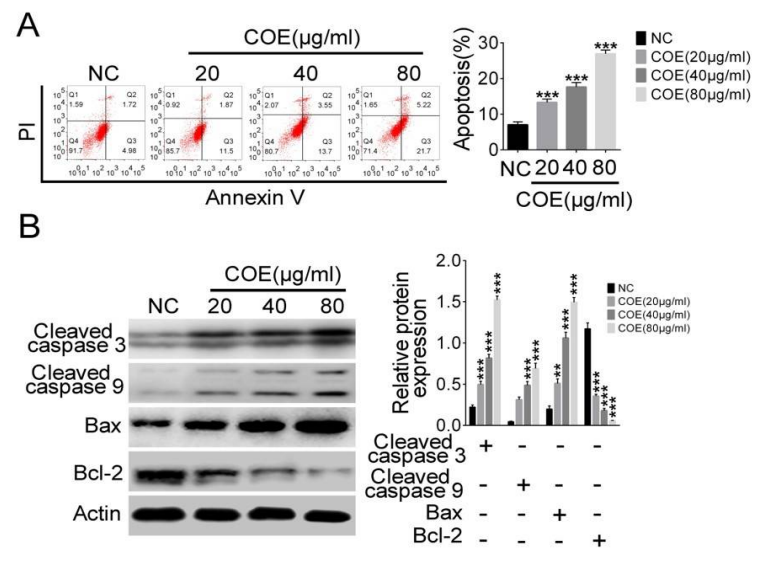

Figure 2: Effect of Celastrus orbiculatus extract (COE) on Tca8113 apoptosis. A: Tca8113 apoptosis at various COE treatment concentrations as measured by flow cytometry. B: Relative expression of apoptosisrelated proteins, assessed with western blot; mean \pm $\mathrm{SD}\left(\mathrm{n}=5,{ }^{* \star *} p<0.001\right.$, compared to NC group)

\section{COE inhibited Tca8113 migration and invasion}

To ascertain whether COE can inhibit the mobility of Tca8113 cells, as well as to test for any anti-tumor effect, COE-treated Tca8113 cells were analyzed using a wound healing assay (Figure $3 \mathrm{~A}$ ). Compared with the control group, COE decreased migration, with concentrations of 20,40 , and $80 \mu \mathrm{g} / \mathrm{mL}$ COE reducing the degree of transmembrane cells to $68 \%(p<0.05), 40 \%$ $(p<0.001)$, and $39 \%(p<0.001)$, respectively. The Transwell chamber method was used to assess the invasiveness of Tca8113 cells (Figure $3 \mathrm{~B})$. The number of transmembrane cells in the negative control group (265 cells) was large and the cell gap was small. The number of transmembrane cells decreased in the COE groups, with concentrations of 20,40 , and 80 $\mu \mathrm{g} / \mathrm{mL}$ reducing the number to $198(p<0.01)$, $134(p<0.001)$, and $78(p<0.001)$, respectively. This indicates that COE significantly reduced the invasiveness of Tca8113 cells, and the effect was dose-dependent.

The relative expressions of selected proteins associated with cell adhesion and migration were measured using western blot (Figure $3 \mathrm{C}$ ).
Expression of E-cadherin and ZO-1 increased with COE treatment, while expression of $\mathrm{N}$ cadherin, vimentin, and MMP-9 decreased. The effect was dose dependent, with the highest dose of COE having a stronger inhibitory effect on Tca8113 migration and invasion.

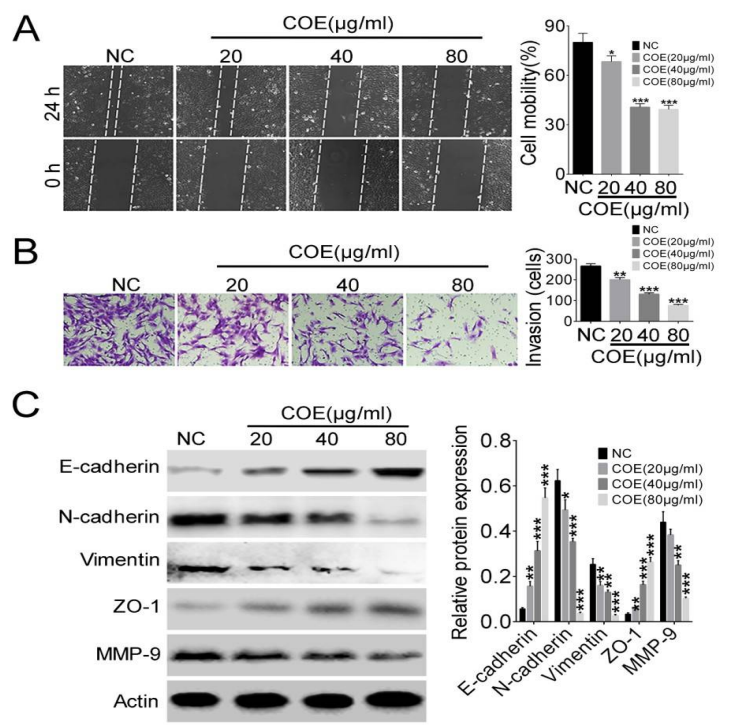

Figure 3: Effect of Celastrus orbiculatus extract (COE) treatment on Tca8113 cell mobility and invasion. A: photographs (left) and quantification (right) of Tca8113 mobility at 0 and $24 \mathrm{~h}$ of the wound healing assay; B: photographs (left) and quantification (right) of Tca8113 cell invasion by Transwell chamber assay. C: Relative expression of migration- and invasion-related proteins assessed with western blot; mean $\pm \mathrm{SD}(\mathrm{n}=5),{ }^{*} p<$ $0.01,{ }^{\star * \star} p<0.001$, compared to NC group)

\section{COE blocked NF-KB pathway in Tca8113 cells}

Western blot analysis was used to investigate the expressions of NF-kB pathway-related proteins IкBa, $p$-IkBa, PARP, and p65 in Tca8113 cells treated with different concentrations of COE. Actin was used as an internal standard for both the cytosol and nucleus. Figure 4 shows that the expression of IKBa increased with $\mathrm{COE}$ concentration, while the expression of $\mathrm{p}-\mathrm{IkB \alpha}$ and p65 was inversely related to COE concentration (all $p<0.001$ ).

The COE significantly inhibited the phosphorylation of $\mathrm{I} \mathrm{KB \alpha}$, and its accumulation in the cytoplasm was increased. The extract also appeared to reduce the recruitment of nuclear p65, suggesting that the classical NF-KB pathway was blocked by COE. Poly ADP-ribose polymerase was not detected in the cytoplasm, which supports successful separation of the cytoplasm and nucleus in this experiment.

Trop J Pharm Res, June 2019; 18(6): 1262 


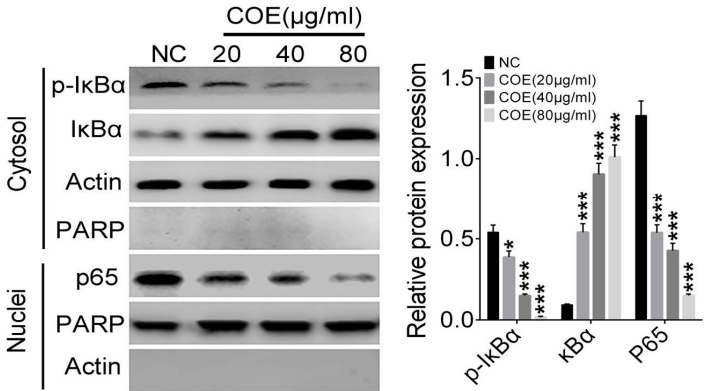

Figure 4: Effect of Celastrus orbiculatus extract (COE) on relative expression of NF-kB pathway proteins in Tca8113 cells, as assessed by western blot. Left panel: Localization of proteins in the cytosol and nucleus. Right panel: expression in the whole cell; mean \pm SD $(n=5)$, $p<0.05$ and ${ }^{* * *} p<0.001$, compared to NC group

\section{DISCUSSION}

The NF-KB family of nuclear transcription factors includes five proteins with a Rel homeodomain: NF-kB1 (p50/p105), NF-kB2 (p52/p100), c-Rel, RelA/p65, and RelB. On activation of these proteins, the dimer has transcription factor activity that regulates gene expression in a variety of biological processes, including innate and adaptive immunity, inflammation, and lymphocyte development [10]. The phosphorylated NF-IKB protein releases the NF$\mathrm{KB} /$ Rel complex, which is itself ubiquitinated and degraded by the ubiquitin-proteasome pathway. The NF-kB/Rel complex translocates to the nucleus and mediates target gene transcription there, either acting alone or in combination with other transcription factors.

The inhibitory effect of serotonin on the NF-KB signaling pathway was discovered during a study of its inhibitory effect on inflammatory cells [11]. Researchers discovered that COE inhibits the production of nitric oxide adhesion and release of lipopolysaccharide-mediated inflammatory cytokines, which is achieved by the NF-IKB protein kinase complex IKK. The NF-KB signaling pathway is present not only in inflammatory cells but also in malignant cells, makingTca8113 cells appropriate for this study of the mechanism of $\mathrm{COE}$ on the inhibition of development of oral squamous cell carcinoma.

Cyclin D1, a subtype of cyclin, forms complexes with CDK4. These two cyclin-dependent kinases are essential for the transition of cells from the G1 to $S$ stages. Cyclin-dependent kinase 2 and CDK4 mainly cause $\mathrm{G} 1 / \mathrm{S}$ phase arrest. It may be that COE inhibits expression of cell-cycle proteins, thereby inhibiting proliferation of Tca8113 cells.
Caspase-3 is the most critical apoptotic executor downstream of the caspase cascade. Its activation is largely dependent on the release of cyt-c. B-cell lymphoma 2 and Bax are the most important regulatory apoptosis genes, and are essential in the upstream regulatory mechanism of caspase-3; the latter is involved in the regulation of caspase- 3 activity, and acts as a direct substrate for caspase-3 downstream [12]. The process is both interconnected and mutually restrictive. It may be that $\mathrm{COE}$ promotes Caspase-3 and Bax expressions, thereby promoting apoptosis of Tca1183 cells.

During the growth of epithelial-derived oral squamous cell carcinoma tumors, the tumor cells lose their epithelial cell characteristics and exhibit the characteristics of interstitial cells. For example, in these carcinoma cells, the epithelial cell markers such as expression of E-cadherin and keratin are decreased or cannot be detected, while the expression of interstitial cell markers such as $\mathrm{N}$-cadherin and vimentin are greater, compared to normal epithelial cells $[13,14]$. During the epithelial-mesenchymal transition, the arrangement of the cells cytoskeleton system changed cell adhesion ability. At that point, cells could easily break away from the primary tumor and invade or metastasize to surrounding tissues. It may be that $\mathrm{COE}$ regulates the expression of these protein markers so that the ability of Tca1183 cells to metastasize is reduced.

\section{CONCLUSION}

This study provides evidence that COE inhibits cell proliferation, cell migration, and invasion of Tcs8113 cells. It also reduces the level of NF-KB protein p65, blocks cell-cycle progression, and promotes apoptosis. Thus, the extract inhibits the expression of MMP-9 by blocking NF-KB signaling pathway and thus, may diminish the metastatic ability of oral squamous cell carcinoma.

\section{DECLARATIONS}

\section{Conflict of interest}

No conflict of interest is associated with this work.

\section{Contribution of authors}

We declare that this work was done by the researchers listed in this article. All liabilities related with the content of this article will be 
borne by the authors. DH and YG designed all the experiments and revised the manuscript. NB, $\mathrm{ZW}, \mathrm{BL}$ and $\mathrm{GT}$ performed the experiments.

\section{Open Access}

This is an Open Access article that uses a funding model which does not charge readers or their institutions for access and distributed under the terms of the Creative Commons Attribution License (http://creativecommons.org/licenses/by/ 4.0) and the Budapest Open Access Initiative (http://www.budapestopenaccessinitiative.org/rea d), which permit unrestricted use, distribution, and reproduction in any medium, provided the original work is properly credited.

\section{REFERENCES}

1. Rastogi B, Kumar A, Raut SK, Panda NK, Rattan V, Joshi N, Khullar M. Downregulation of miR-377 Promotes Oral Squamous Cell Carcinoma Growth and Migration by Targeting HDAC9. Cancer Invest 2017; 35(3): 152-162.

2. Ni $Y-H$, Huang $X-F$, Wang $Z-Y$, Han $W$, Deng $R-Z$, Mou $Y-B$, Ding L, Hou $Y-Y, H u Q-G$. Upregulation of a potential prognostic biomarker, miR-155, enhances cell proliferation in patients with oral squamous cell carcinoma. Oral surg oral med oral pathol oral radiol 2014; 117(2): 227-233.

3. Jian-Juan LI, Jie Y, Fang L, Yin-Tao QI, Liu YQ, Yun S. Chemical constituents from the stems of Celastrus orbiculatus. Chin J Nat Med 2012; 10(4): 279-283.

4. Wang $M$, Zhang $X$, Xiong $X$, Yang $Z$, Sun $Y$, Yang $Z$, Hoffman RM, Liu $Y$. Efficacy of the Chinese traditional medicinal herb Celastrus orbiculatus Thunb on human hepatocellular carcinoma in an orthothopic fluorescent nude mouse model. Anticancer Res 2012; 32(4): 12131220.

5. Zhang H, Qian Y, Liu Y, Li G, Cui P, Zhu Y, Ma H, Xue J, Guo S, Tadashi $H$. Celastrus orbiculatus extract induces mitochondrial-mediated apoptosis in human hepatocellular carcinoma cells. $J$ of Tradit Chin Med 2012; 32(4): 621-626.

6. Li G, Dan L, Guo S, Sunagawa M, Hisamitsu T, Liu Y. Anti-invasive effects of Celastrus Orbiculatus extract on interleukin-1 beta and tumour necrosis factor-alpha combination-stimulated fibroblast-like synoviocytes. BMC Complemnt Altern Med 2014; 14(1): 62-63.

7. Zhu Y, Liu Y, Qian Y, Dai X, Yang L, Chen J, Guo S, Hisamitsu T. Antimetastatic effects of Celastrus orbiculatus on human gastric adenocarcinoma by inhibiting epithelial-mesenchymal transition and NFKB/snail signaling pathway. Integr Cancer Ther 2015; 14(3): 271-281.

8. Zhu Y, Liu Y, Qian Y, Dai X, Yang L, Chen J, Guo S, Hisamitsu $T$. Research on the efficacy of Celastrus Orbiculatus in suppressing TGF- $\beta 1$-induced epithelialmesenchymal transition by inhibiting HSP27 and TNF- $\alpha$ induced NF-K $B /$ Snail signaling pathway in human gastric adenocarcinoma. BMC Complement Altern Med 2014; 14(1): 433-441.

9. Ma H, Qian $Y$, Zhang $H$, Ji $X$, Zhu $Y$, Cui $P$, Liu $Y$. Celastrus orbiculatus extract could inhibit human colorectal carcinoma HT-29 cells metastasis via suppression of the mTOR signaling pathway. Life Sci J 2013; 10(2): 1704-1710.

10. Jr ASB. The NF-KB and IKB proteins: New Discoveries and Insights. Annu Rev Immunol 1996; 14(1): 649-683.

11. Bao $P, W u X$, Xie $S$. Curcumin ameliorates renal impairment in a diabetic rat model. Trop. J. Pharm. Res. 2019; 18(2): 273-278.

12. Krueger A, Baumann S, Krammer PH, Kirchhoff $S$. FLICE-inhibitory proteins: regulators of death receptormediated apoptosis. Mol Cell Biol 2001; 21(24): 82478254.

13. Kim HS, Hong EK, Park SY, Kim WH, Lee HS. Expression of beta-catenin and E-cadherin in the adenoma-carcinoma sequence of the stomach. Anticancer Res 2003; 23(3C): 2863-2871.

14. Zhong J, Liu Z, Liu S. Inhibition of SENP5 by cucurbitacin $B$ suppresses cell growth and promotes apoptosis in osteosarcoma cells. Trop. J. Pharm. Res. 2015; 14(9): 1573-1579. 